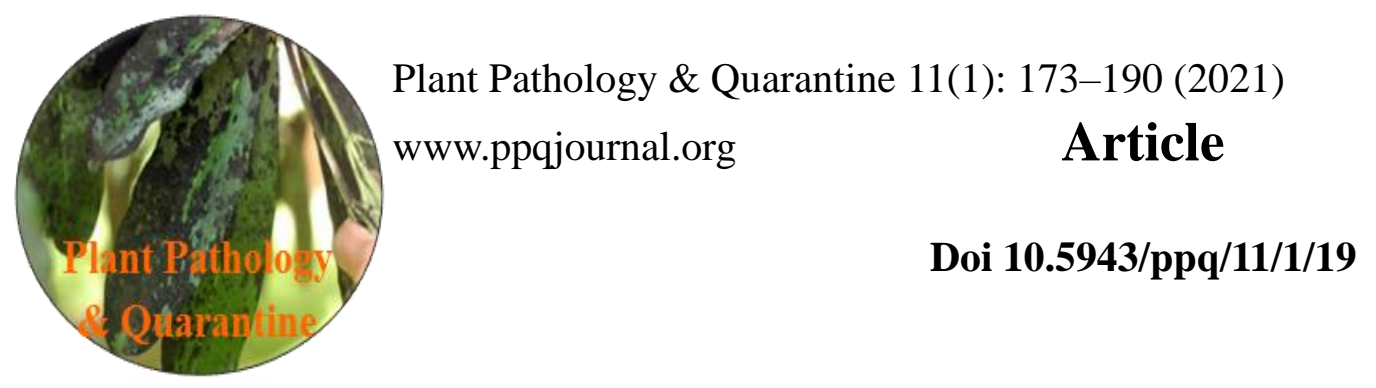

ISSN 2229-2217

\title{
Fungicides in the control of septoriose in tomato plant
}

\author{
Monteiro FP', Ogoshi $\mathrm{C}^{1}$, Cardoso $\mathrm{DA}^{2}$, Perazzoli $\mathbf{V}^{3}$, Maindra $\mathbf{L C}^{5}$, \\ Pinto FAMF ${ }^{4}$, Mallmann $G^{1}$, Valmorbida $\mathrm{J}^{1}$ and Wamser $\mathrm{AF}^{1}$
}

\author{
${ }^{1}$ Researchers at the EPAGRI - Agricultural Research and Rural Extension Enterprise of Santa Catarina, Abílio Franco, \\ 1500, Bom Sucesso, PO Box 591, Zip code 89.501-032, Caçador, Santa Catarina, Brazil \\ ${ }^{2}$ Undergraduate student at the UFSC - Universidade Federal de Santa Catarina, Bernardo Olsen, 400, Centro, \\ Canoinhas, Santa Catarina, Brazil \\ ${ }^{3}$ Undergraduate student at the UNOESC - Universidade do Oeste de Santa Catarina, Paese, 198, Universitário, Videira, \\ Santa Catarina, Brazil \\ ${ }^{4}$ Researchers at the EPAGRI - Agricultural Research and Rural Extension Enterprise of Santa Catarina, João Araújo \\ Lima, 102, Jardim Caiçara, Zip code 88.600-000, São Joaquim, Santa Catarina, Brazil \\ ${ }^{5}$ Uniarp - Universidade do Alto Vale do Rio do Peixe, Rua Victor Baptista Adami, no 800, Zip code 89500-199, \\ Centro, Santa Catarina, Brazil
}

Monteiro FP, Ogoshi C, Cardoso DA, Perazzoli V, Maindra LC, Pinto FAMF, Mallmann G, Valmorbida J, Wamser AF 2021 - Fungicides in the control of septoriose in tomato plant. Plant Pathology \& Quarantine 11(1), 173-190, Doi 10.5943/ppq/11/1/19

\begin{abstract}
The disease septoriose causes severe defoliation in tomato plants that can reach $100 \%$ leaf fall. Consequently, the losses are significant due to the decrease in photoassimilate production and sun scald on tomato fruits. This work presents studies in vitro and in vivo of 15 active ingredients, alone or combined, at the recommended doses to control the septoriose in preventive or curative pulverization. The dose used must follow the fungicide label instructions to keep the resistance risk low and comply with current legislation. In addition, the efficiency of 24 active ingredients, alone or combined, recommended for other tomato diseases than septoriose in preventive pulverization was also explored to know its effect on Septoria lycopersici. In the preventive treatment fluxapyroxad + pyraclostrobin $(58.5+116.6 \mathrm{ppm}$ of the active ingredient, respectively), mancozeb $(4000 \mathrm{ppm})$, difenoconazole $(125 \mathrm{ppm})$, chlorothalonil $(1500 \mathrm{ppm})$, propineb $(2100 \mathrm{ppm})$, fluazinam + thiophanate-methyl $(375+375 \mathrm{ppm})$ and metiram + pyraclostrobin $(1100+100 \mathrm{ppm})$ controlled the severity of the disease above $70 \%$. In the curative treatment, applying the fungicides after seven days from spores pulverization, no fungicide control above $70 \%$ of the disease incidence and severity compared to the treatment without pulverization. Among the fungicides recommended for other tomato diseases than septoriose, those with mancozeb or chlorothalonil in doses higher than 1920 and 1200ppm, respectively, as part of the active ingredients and boscalide (75ppm) controlled above of $70 \%$ of the severity of the disease. The use of multi-site products (mancozeb, chlorothalonil, propineb or metiram) or fluazinam (protective fungicide) combined with efficient systemic fungicides (fluxapyroxad or difenoconazole) at the doses recommended in label for the control of $S$. lycopersici could control tomato septoriose efficiently. Those fungicides should be applied without a tank mixture. The fungicides metiram, fluazinam and fluxapiroxade are recommended to control septoriose in Brazil only when formulated with pyraclostrobin, thiophanate-methyl and pyraclostrobin, respectively.
\end{abstract}


Keywords - Chemical control - Septoria lycopersici - Solanum lycopersicum - Septoria leaf spot

\section{Introduction}

The septoriose was reported for the first time in Argentina in 1882 (Sutton \& Waterston 1966) and nowadays occur anywhere in tomato crops (Stevenson 1991). S. lycopersici infect tomato leaves by both stomata and direct penetration (Martin-Hernandez et al. 2000). This species is the unique etiologic agent of the septoriose in Brazil, and genetic diversity was not found for isolates from Brazil using Tub, Cal and EF1- $\alpha$ sequencing region (Costa 2019). Despite the lack of genetic diversity based on those sequencing regions, the isolates of S. lycopersici have some morphology variability and variation in aggressiveness to tomato plants (Costa 2019). Its importance depends on the favorable weather conditions, which occur when the relative humidity is above $85 \%$; temperature is between 20 to $25^{\circ} \mathrm{C}$ (Kurozawa \& Pavan 2005) and wetting periods greater than 20h (Elmer \& Ferrandino 1995).

Symptoms appear one week after inoculation, and after six weeks, defoliation is close to $100 \%$, and losses are significant due to the sunscald on tomato fruits (Sohi \& Sokhi 1974) when in humid conditions and no control measures are used (Parker et al. 1997). In each cultivation cycle, the disease begins in the leaves of the shallows due to the raindrops that fall on fragments of plants with Septoria spores and cause splashes spreading the spores to the surrounding tomato leaves (Douglas 2008).

Symptoms are circular-shaped spots with darkened edges and brown coloured centres, which initially appear at the bottom of the plant. After a few days, small black spots appear in the centre of the lesions, which correspond to the reproductive structures of the fungus (pycnids). Under favourable conditions, the lesions may coalesce, turn yellow, and then brown, which wither, dry and detach from the plant (Douglas 2008). Similar injuries can occur on the stem. The fruits are rarely affected. It can be confused with a bacterial spot when the lesions are at the beginning or with Alternaria leaf spot. A study to determine resistance to septoriosis with more than 500 plants, including strains, accessions and cultivars revealed that all tested cultivars demonstrated susceptibility to this disease (Poysa et al. 1993). Despite attempts to include septoriose resistance, no commercial cultivar has it. Since there is no genetic resistance, the recommended control tactics include crop rotation with a non-host species, removal of alternative hosts (Datura stramonium, Physalis sp., Solanum carolinense) and cultural remains (Seymour \& Ridings 1980, Zitter 1987, Stevenson 1991, Malnati 1993, Bhardwaj et al. 1995), and the application of the recommended fungicides.

Fungicides, natural or synthetic, protect plants against invasion by fungi or eradicate established fungal infection to ensure the yield potential, measure as the quantity or quality of production (Oliver \& Hewitt 2014). The effectiveness of some fungicides may vary from time to time because pathogens can develop resistance to it. The risk of fungicides resistance varies depending on the number of action sites of the active ingredients (Table 1) and pathogen propensity to develop resistance (Oliver \& Hewitt 2014). Mobility is an important fungicide attribute, which occurs by interplant movement through vapour-phase activity or redistribution by rain, and intraplant movement through xylem or phloem transport and diffusion (Oliver \& Hewitt 2014). Chlorothalonil and metalaxyl, for example, have some redistribution in the air due to the low vapour pressures they have. Fungal structures which are exposed to the air might be susceptible to fungicides active through the vapour phase (Oliver \& Hewitt 2014). In addition, fungicides may reach places that were not sprayed via vapour phase (Oliver \& Hewitt 2014). Fungicides can be systemic, non-systemic, protectant, curative or eradicant, and all those characteristics are important to outline a field management strategy. Systemic fungicide may also possess strong protectant characteristics (Oliver \& Hewitt 2014).

Chemically distinct classes can have the same mode of action (Oliver \& Hewitt 2014), which could be led to an emerging resistant lineage in a case without fungicide group rotation. The fungicide with multi-site action has a lower risk of developing resistant individuals, like dithiocarbamates and chlorothalonil, and because of this, it had been used in combination with 
high-risk compounds to diminish the possibility of fungal resistance (Oliver \& Hewitt 2014). The resistance risk for many groups of fungicides is discussed in Frac (2021).

Table 1 Fungicide mode of action used in tomato crop in Brazil and its modes of action

\begin{tabular}{|c|c|c|}
\hline Active ingredient & Group & Mode of action of fungicides \\
\hline Thiophanate-methyl & Benzimidazole & Mitosis: assembly of $\beta$-tubulin (Frac 2021) \\
\hline $\begin{array}{l}\text { Difenoconazole } \\
\text { Metconazole } \\
\text { Tebuconazole } \\
\text { Trifloxistrobin } \\
\text { Tetraconazole } \\
\end{array}$ & Triazole & Demethylation of C-14 in sterol biosynthesis (Frac 2021) \\
\hline $\begin{array}{l}\text { Mancozeb } \\
\text { Metiram } \\
\text { Propineb } \\
\end{array}$ & Dithiocarbamate & Multi-site contact activity (Frac 2021) \\
\hline $\begin{array}{l}\text { Azoxystrobin } \\
\text { Pyraclostrobin }\end{array}$ & Strobilurins & $\begin{array}{l}\text { Breathing complex 3: ubiquinol oxidase, local Qo (Frac } \\
\text { 2021) }\end{array}$ \\
\hline Chlorothalonil & Chloronitriles & Multi-site contact activity (Frac 2021) \\
\hline $\begin{array}{l}\text { Fluxapyroxad } \\
\text { Boscalid }\end{array}$ & Carboxamide & $\begin{array}{l}\text { Breathing complex 2: succinate dehydrogenase inhibitors } \\
\text { (Frac 2021) }\end{array}$ \\
\hline Benzalkonium chloride & $\begin{array}{l}\text { Quaternary ammonium } \\
\text { compound }\end{array}$ & $\begin{array}{l}\text { Perturbation and disruption of the membrane bilayers } \\
\text { (Wessels \& Ingmer 2013) }\end{array}$ \\
\hline Fluazinam & Phenylpyridinylamine & $\begin{array}{l}\text { Mitochondrial oxidative phosphorylation inhibitors } \\
\text { (Vitoratos 2014) }\end{array}$ \\
\hline Cymoxanil & Acetamide & $\begin{array}{l}\text { Might inhibits nucleic acid and protein biosynthesis } \\
\text { induced via interaction with host metabolic processes } \\
\text { (Joshi 2003) }\end{array}$ \\
\hline $\begin{array}{l}\text { Isopropyl } \\
\text { benthiavalicarb }\end{array}$ & Valinamide carbamate & $\begin{array}{l}\text { Inhibits processes involved in cell-wall biosynthesis and } \\
\text { assembly (Gisi et al. 2019) }\end{array}$ \\
\hline Pyrimethanil & Anilino-pyrimidine & $\begin{array}{l}\text { Methionine aminoacid biosynthesis inhibition, which } \\
\text { affects the protein synthesis (Frac 2021) }\end{array}$ \\
\hline $\begin{array}{l}\text { Iprodione } \\
\text { Procimidone }\end{array}$ & Dicarboxamide & Involve the interference with kinase signalling (Frac 2021) \\
\hline Captan & $\begin{array}{l}\text { Dicarboxamide } \\
\text { (phthalimides) }\end{array}$ & $\begin{array}{l}\text { React with enzyme sulfhydryl groups but may also attack } \\
\text { amino groups and inhibit enzymes that do not contain } \\
\text { sulfhydryl groups (Luo \& Lewis 1992) }\end{array}$ \\
\hline Kasugamycin & Antibiotic & $\begin{array}{l}\text { Binds to the ribosomal subunit 30S and inhibit the protein } \\
\text { elongation (Okuyama et al. 1971) }\end{array}$ \\
\hline Mandipropamid & Mandelic acid amides & $\begin{array}{l}\text { Target the enzyme cellulose synthase that affect the cell } \\
\text { wall biosynthesis (Frac 2021) }\end{array}$ \\
\hline $\begin{array}{l}\text { Propamocarb } \\
\text { hydrochloride }\end{array}$ & Carbamate & $\begin{array}{l}\text { The action is related to membrane function, causing an } \\
\text { efflux of cell compounds (Kilian \& Steiner 2003, } \\
\text { Papavizas et al. 1978) }\end{array}$ \\
\hline Fluopicolide & $\begin{array}{l}\text { Pyridinylmethyl- } \\
\text { benzamide }\end{array}$ & $\begin{array}{l}\text { Affect spectrin-like proteins in the cytoskeleton of } \\
\text { oomycetes (Toquin et al. 2019) }\end{array}$ \\
\hline Metalaxyl-M & Acylalanines & $\begin{array}{l}\text { Inhibiting ribosomal RNA synthesis via the RNA } \\
\text { polymerase I-template complex, which disrupts the protein } \\
\text { synthesis (Fisher \& Hayes 1982) }\end{array}$ \\
\hline Dimethomorph & Carboxylic acid amides & $\begin{array}{l}\text { Affect the cellulose synthase, which interfere in the cell } \\
\text { wall biosynthesis (Kuhn et al. 1991) }\end{array}$ \\
\hline Famoxadone & Oxazolidinedione & $\begin{array}{l}\text { Quinone outside inhibitors affecting the respiration } \\
\text { process (Frac 2021) }\end{array}$ \\
\hline $\begin{array}{l}\text { Copper oxychloride } \\
\text { Copper hydroxide } \\
\text { Cuprous oxide }\end{array}$ & Inorganic & $\begin{array}{l}\text { Inactivate enzymes, which possess sulfhydryl, hydroxyl, } \\
\text { amino or carboxyl groups, leading to a general disruption } \\
\text { of metabolism and breakdown of cell integrity (Frac 2021) }\end{array}$ \\
\hline
\end{tabular}


Scientific data on the efficiency of fungicides in controlling tomato septoriosis are scarce, highlighting the use of chlorothalonil (Poysa \& Tu 1993) and mancozeb (Dillard et al. 1997). The objective of this work was to determine the efficiency of registered and non-registered fungicides for septoriose at the label dosage in Brazil to control this disease.

\section{Materials \& Methods}

\section{In vitro assays}

Mycelial growth evaluation of Septoria when in contact with the registered fungicides at the label dosage

The fungicides were mixed with the culture medium malt-extract $(20 \mathrm{~g}$ malt extract/L and $20 \mathrm{~g}$ agar/L) at the recommended dose for field application (Table 2) to determine the efficiency of the product in inhibiting mycelial growth. The experiment was conducted in Petri dishes of $9 \mathrm{~cm}$. After pouring the culture media mixed with the fungicide, a mycelial disc of $0.5 \mathrm{~cm}$ was placed at the centre. The mycelial growth was measured after 14 days of incubation at $25^{\circ} \mathrm{C}$ and a photoperiod of 12h. The data was transformed into a percentage of the control. The experiment was repeated twice.

Table 2 Concentration (part per million of the active ingredient-ppm) and Frac group code of the registered fungicides for Septoria control in Brazil

\begin{tabular}{lll}
\hline Registered fungicides & ppm of a. $\mathbf{i}^{\mathbf{1}}$ recommended & FRAC code \\
\hline Thiophanate-methyl & 490 & $\mathrm{~B} 1$ \\
Azoxystrobin & 80 & $\mathrm{C} 3$ \\
Benzalkonium chloride & 250 & - \\
Propineb & 2100 & $\mathrm{M} 3$ \\
Tebuconazole & 213 & $\mathrm{G} 1$ \\
Cuprous oxide & $1344(1200)^{2}$ & $\mathrm{M} 1$ \\
Metconazole & 90 & $\mathrm{G} 1$ \\
Metiram + Pyraclostrobin & $1100+100$ & $\mathrm{M} 3+\mathrm{C} 3$ \\
Chlorothalonil & 1500 & $\mathrm{M} 5$ \\
Fluazinam + Thiophanate-methyl & $375+375$ & $\mathrm{~B} 1+\mathrm{C} 5$ \\
Difenoconazole & 125 & $\mathrm{G} 1$ \\
Mancozeb & 4000 & $\mathrm{M} 3$ \\
Fluxapyroxad + Pyraclostrobin & $58.5+116.6$ & $\mathrm{C} 2+\mathrm{C} 3$ \\
Pyraclostrobin & 100 & $\mathrm{C} 3$ \\
Tetraconazole & 75 & $\mathrm{G} 1$ \\
\hline
\end{tabular}

${ }^{1}$ Active ingredient

${ }^{2}$ The value between parentheses is the amount of metallic copper present

Germination of Septoria spores when in contact with the registered fungicides at the label dose - Method 1

The fungicides were mixed with the culture medium water-agar $(20 \mathrm{~g}$ agar/L) at the recommended dose for field application (Table 2) to determine the efficiency of the active ingredient in inhibiting spore germination. The experiment was conducted in Petri dishes of $9 \mathrm{~cm}$. After pouring the culture media mixed with the fungicide, $100 \mu \mathrm{L}$ of a spore suspension at $10^{5}$ spores/mL was spread over the culture media surface. S. lycopersici spores were produced by the method proposed by Monteiro et al. (2019). The spore germination was measured after 2 days from incubation at $25^{\circ} \mathrm{C}$ and a photoperiod of $12 \mathrm{~h}$. The data was transformed into a percentage of the control. The experiment was repeated twice.

Germination of Septoria spores when in contact with the registered fungicides at the label dose - Method 2

The efficiency of the fungicides in inhibiting spore germination was tested by another 
method. The experiment was conducted in Petri dishes of $9 \mathrm{~cm}$. After pouring the culture media malt extract (malt extract $20 \mathrm{~g} / \mathrm{L}$ and agar $20 \mathrm{~g} / \mathrm{L}$ ), $100 \mu \mathrm{L}$ of a spore suspension at $10^{5}$ spores per $\mathrm{ml}$ was spread over the culture media surface using a Drigalski handle. In the centre of the Petri dish was placed $10 \mu \mathrm{L}$ of the fungicides solution at the recommended dose. The inhibition halo was measured after 14 days of incubation at $25^{\circ} \mathrm{C}$ and a photoperiod of $12 \mathrm{~h}$. The data was transformed into a percentage of the control. The experiment was repeated twice.

\section{Mycelial growth influenced by a range of concentrations of some registered fungicide}

The fungicides azoxystrobin, chlorothalonil, cuprous oxide, difenoconazole, mancozeb, metconazole, methyl-thiophanate, propineb, pyraclostrobin, tebuconazol and tetraconazole were mixed in malt culture medium for the final doses of 50, 100, 1000, 2000 and $4000 \mathrm{ppm}$ of active ingredients to know the effect of growing doses on the mycelial growth. Five isolates with morphology differences were used to show how the efficiency of control might change with the Septoria isolate.

\section{Comparison between pyraclostrobin and pyraclostrobin + fluxapyroxad in equivalent doses}

The experiment was performed to know the effect of the pyraclostrobin in the control of the spore germination of Septoria. The dose for pyraclostrobin was $116.6 \mathrm{ppm}$ and for fluxapyroxad + pyraclostrobin were 58.5 and $116.6 \mathrm{ppm}$, respectively. The experiment was conducted in Petri dishes of $9 \mathrm{~cm}$. After pouring the culture media malt extract (malt extract $20 \mathrm{~g} / \mathrm{L}$ and agar $20 \mathrm{~g} / \mathrm{L}$ ), $100 \mu \mathrm{L}$ of a spore suspension at $10^{5}$ spores $/ \mathrm{mL}$ was spread over the culture media surface using a Drigalski handle. In the centre of the Petri dish was placed $10 \mu \mathrm{L}$ of the fungicides solution at the recommended dose. The inhibition halo was measured after 14 days of incubation at $25^{\circ} \mathrm{C}$ and a photoperiod of $12 \mathrm{~h}$.

\section{In vivo assays}

Incidence and severity of septoriose under the effect of the registered fungicides at the label dose in the greenhouse

Tomato plants were cultivated in vessels with five-litre of capacity. When plants reach four leaflets completely developed, fungicides at the recommended doses (Table 2) were sprayed until the rain off point $(1,000 \mathrm{~L} / \mathrm{ha})$. The water used to prepare the fungicides solutions had $\mathrm{pH} 7$. After two hours from the fungicides spraying, a spore suspension at $10^{5}$ spores $/ \mathrm{mL}$ was sprayed over plants. Plants were incubated in a greenhouse for 14 days. After this period, the incidence and severity of the disease were evaluated using a diagrammatic scale for S. lycopersici of the tomato (Monteiro et al. 2021) and via Measure Picture software. The experiment was replicated three times. The data were transformed to the percentage of the control. A fungicide was considered efficient when it was able to control above $70 \%$ of disease incidence and severity compared to the check (without fungicide pulverization).

Incidence and severity of septoriose under the effect of fungicides used to control other diseases (without register for septoriose control) in tomato crops at the label dosage in the greenhouse

To know the effect of the other fungicides not registered for septoriose control, but that is applied in the tomato crop for the control of other pathogens such as Colletotrichum, Fulvia, Stemphylium, Phytophthora, Alternaria, Sclerotinia, Erwinia, Clavibacter or Xanthomonas, we performed an experiment using the major doses in commercial product labels against those pathogens (Table 3). The experiment was performed in the same way as for the recommended fungicides experiment. The experiment was repeated twice. A fungicide was considered efficient when it controlled above $70 \%$ of incidence and severity of the disease compared to the check (without fungicide pulverization). 
Table 3 Non-registered fungicides for Septoria control used in the tomato crop to control other diseases and Frac group codes

\begin{tabular}{lll}
\hline Fungicides & ppm of a.. $\mathbf{i}^{\mathbf{2}}$ recommended & FRAC code \\
\hline Cymoxanil + Famoxadone & $240+180$ & $\mathrm{Unknown}+\mathrm{C} 3$ \\
Isopropyl benthiavalicarb + Chlorothalonil & $93.75+937.50$ & $\mathrm{H} 5+\mathrm{M} 5$ \\
Pyrimethanil & 900 & $\mathrm{D} 1$ \\
Iprodione & 750 & $\mathrm{E} 3$ \\
Kasugamycin & 60 & $\mathrm{D} 3$ \\
Procymidone & 750 & $\mathrm{E} 3$ \\
Mandipropamid & 150 & $\mathrm{H} 5$ \\
Propamocarb hydrochloride & 2166 & $\mathrm{~F} 4$ \\
Propamocarb hydrochloride + Fluopicolide & $937.5+93.75$ & $\mathrm{~F} 4+\mathrm{B} 5$ \\
Chlorothalonil + Metalaxyl-M & $1200+120$ & $\mathrm{M} 5+\mathrm{A} 1$ \\
Captan & 1200 & $\mathrm{M} 4$ \\
Dimethomorph & 750 & $\mathrm{H} 5$ \\
Trifloxystrobin + Tebuconazole & $75+150$ & $\mathrm{C} 3+\mathrm{G} 1$ \\
Boscalid & 75 & $\mathrm{C} 2$ \\
Azoxystrobin + Diphenoconazole & $80+50$ & $\mathrm{C} 3+\mathrm{G} 1$ \\
Fluazinam & 500 & $\mathrm{C} 5$ \\
Metiram & 2100 & $\mathrm{M} 3$ \\
Copper oxychloride & $1680(1000)^{1}$ & $\mathrm{M} 1$ \\
Copper hydroxide & $2073(1350)^{1}$ & $\mathrm{M} 1$ \\
Metalaxyl-M + Mancozeb & $120+1920$ & $\mathrm{~A} 1+\mathrm{M} 3$ \\
Cymoxanil + Mancozeb & $240+1920$ & $\mathrm{Unknown}+\mathrm{M} 3$ \\
Isopropyl bentiavalicarb + Fluazinam & $70+175$ & $\mathrm{H} 5+\mathrm{C} 5$ \\
Copper oxychloride + Mancozeb & $600(340)^{1}+880$ & $\mathrm{M} 1+\mathrm{M} 3$ \\
Famoxadone + Mancozeb & $100+1000$ & $\mathrm{C} 3+\mathrm{M} 3$ \\
Azoxystrobin + Mancozeb & $166.65+2333.10$ & $\mathrm{C} 3+\mathrm{M} 3$ \\
\hline
\end{tabular}

${ }^{1}$ The value between parentheses is the amount of metallic copper present

${ }^{2}$ Active ingredient

\section{Curative effect of the fungicides applied after seven days from spore pulverization}

Tomato plants were cultivated in vessels with five-litre of capacity. When plants reach four leaflets completely developed, the spore suspension at $10^{5}$ spores $/ \mathrm{mL}$ was sprayed over plants. The fungicides were applied after the appearance of the first symptom (seven days after spores pulverization) at the doses in commercial product labels (Table 2). The water used to prepare the fungicides solutions had $\mathrm{pH}$ 7. Plants were incubated in a greenhouse for 14 days. After this period, the incidence and severity of the disease were evaluated using a diagrammatic scale for $S$. lycopersici of the tomato (Monteiro et al. 2021) and via Measure picture software. The experiment was replicated twice. The data were transformed to percentage of the control.

Control of $S$. lycopersici in the field comparing a fungicide with seven days of withholding period and another with one day of withholding period

We performed a field experiment with pyraclostrobin + fluxapiroxad and pyraclostrobin at the doses in commercial product labels (Table 2) to study whether using a fungicide with a lower withholding period, since the harvest of tomatoes can be made three times per week. In addition, this experiment was performed to know the contribution of the pyraclostrobin ( 1 day of withholding period), when it is used together with fluxapiroxad (7 days of withholding period). Tomato plants were cultivated in a field. The space was $45 \mathrm{~cm}$ and $1 \mathrm{~m}$ between plants and lines, respectively, and each line had 20 tomato plants. When plants reach four leaflets completely developed, the fungicides at the recommended doses were sprayed until the rain off point $(1,000 \mathrm{~L} / \mathrm{ha})$. The water used to prepare the fungicides solutions had $\mathrm{pH} 7$. After two hours from the fungicides spraying, a spore suspension at $10^{5}$ spores/mL was sprayed over plants. After 14 days 
from the pulverization, the incidence and the severity of the disease was evaluated by using a diagrammatic scale for S. lycopersici of the tomato (Monteiro et al. 2021) and by via Measure picture software. The data was transformed to the percentage of the control. A fungicide was considered efficient when it was able to control above $70 \%$ of the incidence and severity of the disease compared to the check (without fungicide pulverization).

\section{Phytotoxicity effect of fungicides applied on tomato plants}

Some fungicides had a phytotoxic effect while conducting the previous experiments. Because of that, we experimented to confirm this deleterious effect at the recommended dose. Nine plants and three replicates composed each treatment. This experiment was performed with metconazole (90ppm), pyraclostrobin (100ppm), pyrimethanil (900ppm), tebuconazole (213ppm), tetraconazole (75ppm) and one treatment without fungicide pulverization.

\section{Statistical analyses}

The results were submitted to analysis of variance, when significant by the $\mathrm{F}$ test, the means were compared by the Scott-Knott statistical test at $5 \%$ of probability $(P \leq 0.05)$.

\section{Results}

Excepted for the fungicides thiophanate-methyl and azoxystrobin, all fungicides control over $80 \%$ of the S. lycopersici mycelial growth. By method 1, thiophanate-methyl and azoxystrobin were the only fungicides that allowed some spore germination. By method 2, the fungicides that prevent the germination of the spores were fluxapyroxad + pyraclostrobin, mancozeb, difenoconazole, fluazinam + thiophanate-methyl, benzalkonium chloride, chlorothalonil and metiram + pyraclostrobin (Table 4$)$.

Table 4 In vitro assays for fungicides registered to control S. lycopersici in tomato crop

\begin{tabular}{|c|c|c|c|c|c|c|}
\hline \multirow{3}{*}{$\begin{array}{l}\text { Registered } \\
\text { fungicides }\end{array}$} & \multicolumn{2}{|c|}{ Mycelial growth } & \multicolumn{4}{|c|}{ Spore germination } \\
\hline & \multirow{2}{*}{$\begin{array}{l}\text { Control } \\
(\%)\end{array}$} & \multirow{2}{*}{$\begin{array}{l}\text { Control } \\
(\%)^{1}\end{array}$} & \multicolumn{2}{|c|}{ Method 1} & \multicolumn{2}{|c|}{ Method 2 } \\
\hline & & & $\begin{array}{l}\text { Control } \\
(\%)\end{array}$ & $\begin{array}{l}\text { Control } \\
(\%)^{1}\end{array}$ & $\begin{array}{l}\text { Control } \\
(\%)\end{array}$ & $\begin{array}{l}\text { Control } \\
(\%)^{1}\end{array}$ \\
\hline Check & $0 c^{3}$ & $0 \mathrm{e}$ & $0 \mathrm{~d}$ & $0 \mathrm{~d}$ & $0 \mathrm{~g}$ & $0 \mathrm{f}$ \\
\hline Thiophanate-methyl & $50.82 \pm$ & $33.25 \pm$ & $95.84 \pm$ & $98.61 \pm$ & $0 \mathrm{~g}$ & $0 \mathrm{f}$ \\
\hline Azoxystrobin & $\begin{array}{l}28.8 \mathrm{I}^{2} \mathrm{~b} \\
53.86 \pm \\
5.27 \mathrm{~b}\end{array}$ & $\begin{array}{l}12.26 \mathrm{~d} \\
47.80 \pm \\
4.23 \mathrm{c}\end{array}$ & $\begin{array}{l}1.32 \mathrm{~b} \\
92.41 \pm \\
1.02 \mathrm{c}\end{array}$ & $\begin{array}{l}0.60 \mathrm{~b} \\
97.91 \pm \\
1.04 \mathrm{c}\end{array}$ & $0 \mathrm{~g}$ & $0 \mathrm{f}$ \\
\hline $\begin{array}{l}\text { Benzalkonium } \\
\text { chloride }\end{array}$ & $\begin{array}{l}94.34 \pm \\
6.27\end{array}$ & $\begin{array}{l}85.54 \pm \\
1.55 \mathrm{~b}\end{array}$ & $100 \mathrm{a}$ & $100 \mathrm{a}$ & $\begin{array}{l}12.04 \pm \\
1.79 \mathrm{e}\end{array}$ & $\begin{array}{l}13.89 \pm \\
1.81 \mathrm{~d}\end{array}$ \\
\hline Propineb & $100 \mathrm{a}$ & $100 \mathrm{a}$ & $100 \mathrm{a}$ & $100 \mathrm{a}$ & $0 \mathrm{~g}$ & $0 \mathrm{f}$ \\
\hline Tebuconazole & $100 \mathrm{a}$ & $100 \mathrm{a}$ & $100 \mathrm{a}$ & $100 \mathrm{a}$ & $0 \mathrm{~g}$ & $0 \mathrm{f}$ \\
\hline Cuprous oxide & $100 \mathrm{a}$ & $100 \mathrm{a}$ & $100 \mathrm{a}$ & $100 \mathrm{a}$ & $0 \mathrm{~g}$ & $0 \mathrm{f}$ \\
\hline Metconazole & $100 \mathrm{a}$ & $100 \mathrm{a}$ & $100 \mathrm{a}$ & $100 \mathrm{a}$ & $0 \mathrm{~g}$ & $0 \mathrm{f}$ \\
\hline $\begin{array}{l}\text { Metiram + } \\
\text { Pyraclostrobin }\end{array}$ & $100 \mathrm{a}$ & $100 \mathrm{a}$ & $100 \mathrm{a}$ & $100 \mathrm{a}$ & $\begin{array}{l}1.85 \pm \\
1.60 \mathrm{~g}\end{array}$ & $\begin{array}{l}8.04 \pm \\
3.72 \mathrm{e}\end{array}$ \\
\hline Chlorothalonil & $100 \mathrm{a}$ & $100 \mathrm{a}$ & $100 \mathrm{a}$ & $100 \mathrm{a}$ & $\begin{array}{l}7.59 \pm \\
5.01 \mathrm{f}\end{array}$ & $\begin{array}{l}27.47 \pm \\
2.04 \mathrm{~b}\end{array}$ \\
\hline $\begin{array}{l}\text { Fluazinam + } \\
\text { Thiophanate-methyl }\end{array}$ & $100 \mathrm{a}$ & $100 \mathrm{a}$ & $100 \mathrm{a}$ & $100 \mathrm{a}$ & $\begin{array}{l}19.82 \pm \\
2.25 \mathrm{~d}\end{array}$ & $\begin{array}{l}16.08 \pm \\
3.17 \mathrm{~d}\end{array}$ \\
\hline Difenoconazole & $100 \mathrm{a}$ & $100 \mathrm{a}$ & $100 \mathrm{a}$ & $100 \mathrm{a}$ & $\begin{array}{l}28.52 \pm \\
5.04 \mathrm{c}\end{array}$ & $\begin{array}{l}19.70 \pm \\
4.07 \mathrm{c}\end{array}$ \\
\hline Mancozeb & $100 \mathrm{a}$ & $100 \mathrm{a}$ & $100 \mathrm{a}$ & $100 \mathrm{a}$ & $\begin{array}{l}48.52 \pm \\
5.16 \mathrm{~b}\end{array}$ & $\begin{array}{l}47.38 \pm \\
1.98 \mathrm{a}\end{array}$ \\
\hline $\begin{array}{l}\text { Fluxapyroxad + } \\
\text { Pyraclostrobin }\end{array}$ & $100 \mathrm{a}$ & $100 \mathrm{a}$ & $100 \mathrm{a}$ & $100 \mathrm{a}$ & $\begin{array}{l}61.48 \pm \\
2.25 \mathrm{a}\end{array}$ & $\begin{array}{l}46.27 \pm \\
1.18 \mathrm{a}\end{array}$ \\
\hline CV $(\%)$ & 7.09 & 3.48 & 0.24 & 0.17 & 11.99 & 11.44 \\
\hline
\end{tabular}


${ }^{1}$ Experiment replication

${ }^{2}$ Values presented after the symbol \pm are standard deviations

${ }^{3}$ The same means in columns were not different compared by the Scott-Knott statistical test at $5 \%$ of probability $(P \leq 0.05)$

Mancozeb, difenoconazole, metconazole, tetraconazole, chlorothalonil and propineb at the doses of 50,100,1000, 2000 and 4000ppm active ingredients controlled 100\% of the mycelial growth of five $S$. lycopersici isolates. Tebuconazole allows the growth of two isolates at the 50ppm active ingredient. Pyraclostrobin, methyl-thiophanate, cuprous oxide and azoxystrobin control depend on the concentration and Septoria isolate (Fig. 1). Azoxystrobin, methyl-thiophanate and pyraclostrobin at the recommended dose seem not sufficient to control $100 \%$ of the mycelial growth (Fig. 1).

For incidence, considering the average value of the percentage of control of the three replicates, the fungicides that had the percentage of control above $70 \%$ were fluxapyroxad+pyraclostrobin, mancozeb, difenoconazole, chlorothalonil, propineb and fluazinam+thiophanate-methyl $(95.64 ; 89,36 ; 89.14 ; 75.69 ; 70.66$ and $70.42 \%$ of control, respectively). For severity, the fungicides that had the percentage of control above $70 \%$, on average of the percentage of control of the three replicates were fluxapyroxad + pyraclostrobin, mancozeb, difenoconazole, chlorothalonil, propineb, fluazinam + thiophanate-methyl and metiram+pyraclostrobin $(97.77 ; 89.89 ; 92.26 ; 86.89 ; 78.97 ; 85.09$ and $75.48 \%$ of control, respectively) (Table 5).
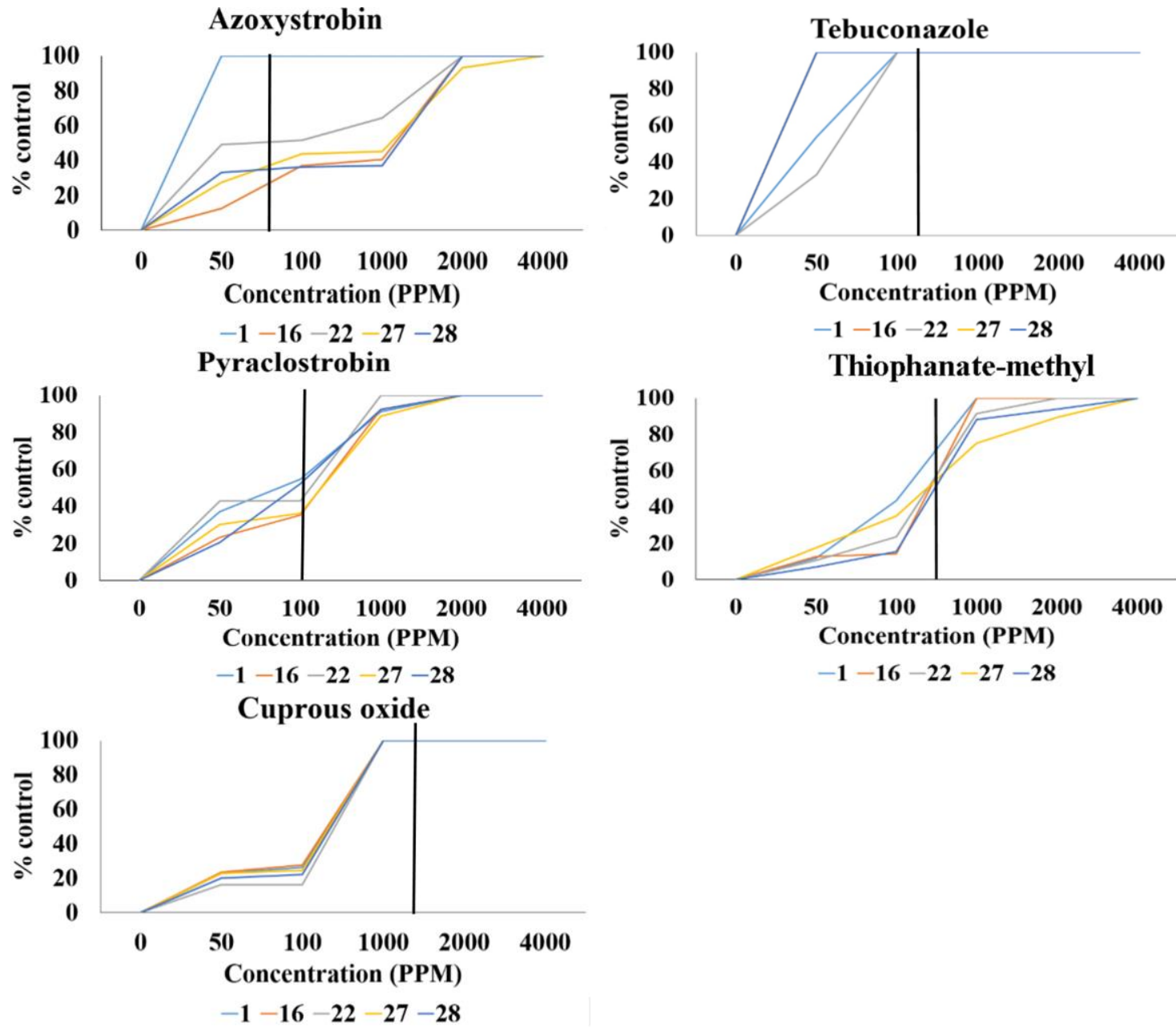

Fig. 1 - Percentage of control of the mycelial growth of S. lycopersici under five doses of the registered fungicides. Black vertical bars indicate the recommended doses of the active ingredient and colored lines indicate the S. lycopersici isolates. 
After the appearance of the first symptoms, seven days from the spores pulverization, no fungicides was considered efficient, because they did not control above $70 \%$ of the incidence and severity compared to the treatment without fungicides (Table 6).

Table 5 In vivo assays measuring incidence and severity of S. lycopersici affected by the preventive pulverization of the registered fungicides

\begin{tabular}{|c|c|c|c|c|c|c|c|c|c|c|c|c|}
\hline \multirow{2}{*}{$\begin{array}{l}\text { Registered } \\
\text { fungicides }\end{array}$} & \multicolumn{2}{|c|}{ Exp. 1} & \multicolumn{2}{|c|}{ Exp. 2} & \multicolumn{2}{|c|}{ Exp. 3} & \multicolumn{2}{|c|}{ Exp. 1} & \multicolumn{2}{|c|}{ Exp. 2} & \multicolumn{2}{|c|}{ Exp. 3} \\
\hline & Incidence & $\begin{array}{l}\text { Control } \\
(\%)\end{array}$ & Incidence & $\begin{array}{l}\text { Control } \\
(\%)\end{array}$ & Incidence & $\begin{array}{l}\text { Control } \\
(\%)\end{array}$ & Severity & $\begin{array}{l}\text { Control } \\
(\%)\end{array}$ & Severity & $\begin{array}{l}\text { Control } \\
(\%)\end{array}$ & Severity & $\begin{array}{l}\text { Control } \\
(\%)\end{array}$ \\
\hline Fluxapyroxad + & $3.25 \pm$ & $95.24 \pm$ & $0.00 \pm$ & $100.00 \pm$ & $3.00 \pm$ & $91.67 \pm$ & $0.20 \pm$ & $99.80 \pm$ & $0.00 \pm$ & $100.00 \pm$ & $6.44 \pm$ & $93.52 \pm$ \\
\hline Pyraclostrobin & $2.17 \mathrm{a}^{23}$ & 3.17 & $0.00 \mathrm{a}$ & 0.00 & $1.47 \mathrm{a}$ & 4.09 & $0.15 \mathrm{a}$ & 0.15 & $0.00 \mathrm{a}$ & 0.00 & $2.95 \mathrm{a}$ & 2.97 \\
\hline \multirow[t]{2}{*}{ Mancozeb } & $5.75 \pm$ & $91.58 \pm$ & $5.75 \pm$ & $91.32 \pm$ & $5.33 \pm$ & $85.19 \pm$ & $8.76 \pm$ & $91.25 \pm$ & $0.76 \pm$ & $91.82 \pm$ & $13.33 \pm$ & $86.59 \pm$ \\
\hline & $1.79 \mathrm{a}$ & 2.62 & $3.11 \mathrm{~b}$ & 4.70 & $2.63 \mathrm{a}$ & 7.29 & $4.43 \mathrm{a}$ & 4.43 & $0.31 \mathrm{a}$ & 3.38 & $5.14 \mathrm{a}$ & 5.17 \\
\hline \multirow[t]{2}{*}{ Difenoconazole } & $7.25 \pm$ & $89.38 \pm$ & $3.50 \pm$ & $94.72 \pm$ & $6.00 \pm$ & $83.33 \pm$ & $0.51 \pm$ & $99.49 \pm$ & $0.37 \pm$ & $96.00 \pm$ & $18.58 \pm$ & $81.30 \pm$ \\
\hline & $4.66 \mathrm{a}$ & 6.82 & $2.29 \mathrm{~b}$ & 3.46 & $2.16 \mathrm{a}$ & 6.00 & $0.35 \mathrm{a}$ & 0.35 & $0.35 \mathrm{a}$ & 3.78 & $9.30 \mathrm{a}$ & 9.36 \\
\hline \multirow[t]{2}{*}{ Chlorothalonil } & $22.50 \pm$ & $67.03 \pm$ & $11.75 \pm$ & $82.26 \pm$ & $8.00 \pm$ & $77.78 \pm$ & $9.86 \pm$ & $90.14 \pm$ & $0.79 \pm$ & $91.48 \pm$ & $20.83 \pm$ & $79.04 \pm$ \\
\hline & $6.18 \mathrm{~b}$ & 9.06 & $2.95 \mathrm{c}$ & 4.45 & $1.41 \mathrm{~b}$ & 3.93 & $4.25 \mathrm{~b}$ & 4.25 & $0.34 \mathrm{a}$ & 3.64 & $12.18 \mathrm{~b}$ & 12.25 \\
\hline \multirow[t]{2}{*}{ Propineb } & $24.00 \pm$ & $64.84 \pm$ & $10.50 \pm$ & $84.15 \pm$ & $13.33 \pm$ & $62.99 \pm$ & $27.24 \pm$ & $72.77 \pm$ & $0.83 \pm$ & $91.06 \pm$ & $26.75 \pm$ & $73.08 \pm$ \\
\hline & $8.06 \mathrm{~b}$ & 11.81 & $2.60 \mathrm{c}$ & 3.92 & $4.50 \mathrm{c}$ & 12.49 & $20.00 \mathrm{c}$ & 20.00 & $0.32 \mathrm{a}$ & 3.44 & $21.79 \mathrm{~b}$ & 21.93 \\
\hline Fluazinam + & $34.00 \pm$ & $50.18 \pm$ & $10.75 \pm$ & $83.77 \pm$ & $8.17 \pm$ & $77.31 \pm$ & $10.85 \pm$ & $89.15 \pm$ & $1.04 \pm$ & $88.77 \pm$ & $22.50 \pm$ & $77.36 \pm$ \\
\hline $\begin{array}{l}\text { Thiophanate- } \\
\text { methyl }\end{array}$ & $6.44 \mathrm{c}$ & 9.44 & $2.95 \mathrm{c}$ & 4.45 & $3.17 \mathrm{~b}$ & 8.81 & $3.28 \mathrm{~b}$ & 3.28 & $0.50 \mathrm{a}$ & 5.44 & $9.19 \mathrm{~b}$ & 9.24 \\
\hline Metiram + & $43.50 \pm$ & $36.26 \pm$ & $17.75 \pm$ & $73.21 \pm$ & $6.33 \pm$ & $82.41 \pm$ & $27.61 \pm$ & $72.39 \pm$ & $1.48 \pm$ & $84.07 \pm$ & $29.83 \pm$ & $69.98 \pm$ \\
\hline Pyraclostrobin & $2.60 \mathrm{~d}$ & 3.81 & $9.26 \mathrm{c}$ & 13.98 & $3.30 \mathrm{a}$ & 9.17 & $19.63 \mathrm{c}$ & 19.63 & $0.80 \mathrm{a}$ & 8.69 & $16.28 \mathrm{~b}$ & 16.38 \\
\hline Benzalkonium & $45.00 \pm$ & $34.07 \pm$ & $20.00 \pm$ & $69.81 \pm$ & $23.00 \pm$ & $36.11 \pm$ & $25.87 \pm$ & $74.13 \pm$ & $3.33 \pm$ & $64.05 \pm$ & $41.25 \pm$ & $58.49 \pm$ \\
\hline chloride & $3.67 \mathrm{~d}$ & 5.38 & $11.51 \mathrm{c}$ & 17.38 & $5.89 \mathrm{c}$ & 16.36 & $11.13 \mathrm{c}$ & 11.13 & $1.55 \mathrm{a}$ & 16.71 & $13.62 \mathrm{~b}$ & 13.70 \\
\hline \multirow[t]{2}{*}{ Cuprous oxide } & $58.00 \pm$ & $15.02 \pm$ & $41.00 \pm$ & $38.11 \pm$ & $20.83 \pm$ & $42.13 \pm$ & $33.54 \pm$ & $66.46 \pm$ & $16.86 \pm$ & $0.00 \pm$ & $63.13 \pm$ & $36.48 \pm$ \\
\hline & $20.32 \mathrm{e}$ & 29.78 & $14.73 \mathrm{~d}$ & 22.24 & $7.53 \mathrm{c}$ & 20.92 & $2.63 \mathrm{c}$ & 2.63 & $10.80 \mathrm{c}$ & 0.00 & $38.71 \mathrm{c}$ & 38.95 \\
\hline \multirow{2}{*}{$\begin{array}{l}\text { Thiophanate- } \\
\text { methyl }\end{array}$} & $64.00 \pm$ & $6.23 \pm$ & $52.00 \pm$ & $21.51 \pm$ & $17.67 \pm$ & $50.92 \pm$ & $95.20 \pm$ & $4.80 \pm$ & $22.46 \pm$ & $0.00 \pm$ & $36.56 \pm$ & $63.21 \pm$ \\
\hline & $28.10 \mathrm{e}$ & 41.17 & $23.88 \mathrm{~d}$ & 36.04 & $6.36 \mathrm{c}$ & 17.65 & $7.25 \mathrm{~d}$ & 7.25 & $11.99 \mathrm{c}$ & 0.00 & $40.74 \mathrm{~b}$ & 40.99 \\
\hline \multirow[t]{2}{*}{ Azoxystrobin } & $64.50 \pm$ & $5.49 \pm$ & $52.50 \pm$ & $20.75 \pm$ & $33.00 \pm$ & $8.33 \pm$ & $92.22 \pm$ & $7.78 \pm$ & $20.22 \pm$ & $0.00 \pm$ & $99.17 \pm$ & $0.21 \pm$ \\
\hline & $11.97 \mathrm{e}$ & 17.54 & $14.53 \mathrm{~d}$ & 21.94 & $5.66 \mathrm{~d}$ & 15.71 & $10.41 \mathrm{~d}$ & 10.41 & $14.46 \mathrm{c}$ & 0.00 & $1.18 \mathrm{~d}$ & 1.19 \\
\hline \multirow[t]{2}{*}{ Check } & $68.20 \pm$ & $0.00 \pm$ & $66.25 \pm$ & $0.00 \pm$ & $36.00 \pm$ & $0.00 \pm$ & $100.00 \pm$ & $0.00 \pm$ & $9.26 \pm$ & $0.00 \pm$ & $98.38 \pm$ & $0.00 \pm$ \\
\hline & $7.98 \mathrm{e}$ & 0.00 & $7.79 \mathrm{e}$ & 0.00 & $7.75 \mathrm{~d}$ & 0.00 & $0.00 \mathrm{~d}$ & 0.00 & $5.46 \mathrm{~b}$ & 0.00 & $1.25 \mathrm{~d}$ & 0.00 \\
\hline Metconazole $^{1}$ & - & - & - & - & - & - & - & - & - & - & - & - \\
\hline Tebuconazole ${ }^{1}$ & - & - & - & - & - & - & - & - & - & - & - & - \\
\hline CV $(\%)$ & 14.68 & & 21.14 & & 17.10 & & 17.17 & & 36.97 & & 25.06 & \\
\hline
\end{tabular}

${ }^{1}$ Those fungicides had a phytotoxic effect

${ }^{2}$ Values presented after the symbol \pm are standard deviations 
${ }^{3}$ Means followed by the same letters in columns were not different when compared by the Scott-Knott statistical test at $5 \%$ of probability $(P \leq 0.05)$

Table 6 Fungicides applied after seven days from spores pulverization as curative treatment

\begin{tabular}{|c|c|c|c|c|c|c|c|c|}
\hline \multirow[t]{2}{*}{ Registered fungicides } & \multicolumn{2}{|c|}{ Exp. 1} & \multicolumn{2}{|c|}{ Exp. 2} & \multicolumn{2}{|c|}{ Exp. 1} & \multicolumn{2}{|c|}{ Exp. 2} \\
\hline & Incidence & Control (\%) & Incidence & Control (\%) & Severity & Control (\%) & Severity & Control (\%) \\
\hline \multirow[t]{2}{*}{ Fluxapyroxad + Pyraclostrobin } & $9.50 \pm$ & $51.28 \pm$ & $16.50 \pm$ & $53.52 \pm$ & $26.88 \pm$ & $63.56 \pm$ & $54.38 \pm$ & $45.63 \pm$ \\
\hline & $1.91 \mathrm{a}^{23}$ & 9.82 & $5.00 \mathrm{a}$ & 14.09 & $8.75^{\mathrm{ns}}$ & 11.86 & $35.14 \mathrm{a}$ & 35.14 \\
\hline \multirow[t]{2}{*}{ Metiram + Pyraclostrobin } & $11.00 \pm$ & $43.59 \pm$ & $27.75 \pm$ & $21.83 \pm$ & $39.38 \pm$ & $46.61 \pm$ & $100.00 \pm$ & $0.00 \pm$ \\
\hline & $3.74 \mathrm{a}$ & 19.19 & $9.57 \mathrm{~b}$ & 26.96 & 17.49 & 23.71 & $0.00 \mathrm{c}$ & 0.00 \\
\hline \multirow[t]{2}{*}{ Difenoconazole } & $10.00 \pm$ & $48.72 \pm$ & $18.25 \pm$ & $48.59 \pm$ & $56.88 \pm$ & $22.88 \pm$ & $73.75 \pm$ & $26.25 \pm$ \\
\hline & $2.45 \mathrm{a}$ & 12.72 & $4.19 \mathrm{a}$ & 11.81 & 30.23 & 40.99 & $20.56 b$ & 20.56 \\
\hline \multirow[t]{2}{*}{ Tetraconazole } & $11.50 \pm$ & $41.03 \pm$ & $19.25 \pm$ & $45.77 \pm$ & $40.00 \pm$ & $45.76 \pm$ & $31.25 \pm$ & $68.75 \pm$ \\
\hline & $4.12 \mathrm{a}$ & 21.14 & $3.30 \mathrm{a}$ & 9.31 & 29.58 & 40.11 & $22.78 \mathrm{a}$ & 22.78 \\
\hline \multirow[t]{2}{*}{ Propineb } & $14.67 \pm$ & $24.78 \pm$ & $29.00 \pm$ & $18.31 \pm$ & $56.88 \pm$ & $22.88 \pm$ & $100.00 \pm$ & $0.00 \pm$ \\
\hline & $2.05 \mathrm{~b}$ & 10.54 & $3.56 \mathrm{~b}$ & 10.03 & 49.81 & 67.53 & $0.00 \mathrm{c}$ & 0.00 \\
\hline \multirow[t]{2}{*}{ Mancozeb } & $14.00 \pm$ & $28.21 \pm$ & $27.33 \pm$ & $23.00 \pm$ & $43.75 \pm$ & $40.68 \pm$ & $81.25 \pm$ & $18.75 \pm$ \\
\hline & $4.32 \mathrm{~b}$ & 22.16 & $1.89 \mathrm{~b}$ & 5.31 & 26.97 & 36.56 & $37.50 \mathrm{c}$ & 37.50 \\
\hline \multirow[t]{2}{*}{ Tebuconazole $^{1}$} & $12.75 \pm$ & $34.62 \pm$ & $20.75 \pm$ & $41.55 \pm$ & $36.88 \pm$ & $50.00 \pm$ & $68.13 \pm$ & $31.88 \pm$ \\
\hline & $2.22 \mathrm{a}$ & 11.37 & $4.92 \mathrm{a}$ & 13.87 & 10.08 & 13.67 & $31.45 \mathrm{~b}$ & 31.45 \\
\hline \multirow[t]{2}{*}{ Fluazinam + Thiophanate-methyl } & $13.50 \pm$ & $30.77 \pm$ & $21.25 \pm$ & $40.14 \pm$ & $65.00 \pm$ & $11.86 \pm$ & $100.00 \pm$ & $0.00 \pm$ \\
\hline & $3.87 \mathrm{a}$ & 19.86 & $4.27 \mathrm{a}$ & 12.03 & 25.58 & 34.68 & $0.00 \mathrm{c}$ & 0.00 \\
\hline \multirow[t]{2}{*}{ Benzalkonium chloride } & $14.00 \pm$ & $28.21 \pm$ & $30.25 \pm$ & $14.79 \pm$ & $65.00 \pm$ & $11.86 \pm$ & $100.00 \pm$ & $0.00 \pm$ \\
\hline & $1.83 \mathrm{~b}$ & 9.36 & $4.03 \mathrm{~b}$ & 11.36 & 37.64 & 51.04 & $0.00 \mathrm{c}$ & 0.00 \\
\hline \multirow[t]{2}{*}{ Pyraclostrobin } & $15.50 \pm$ & $20.51 \pm$ & $28.00 \pm$ & $21.13 \pm$ & $60.63 \pm$ & $17.80 \pm$ & $100.00 \pm$ & $0.00 \pm$ \\
\hline & $1.73 \mathrm{~b}$ & 8.88 & $3.74 \mathrm{~b}$ & 10.54 & 17.37 & 23.55 & $0.00 \mathrm{c}$ & 0.00 \\
\hline \multirow[t]{2}{*}{ Thiophanate-methyl } & $15.75 \pm$ & $19.23 \pm$ & $26.25 \pm$ & $26.06 \pm$ & $73.75 \pm$ & $0.00 \pm$ & $100.00 \pm$ & $0.00 \pm$ \\
\hline & $2.06 \mathrm{~b}$ & 10.57 & $8.81 \mathrm{~b}$ & 24.81 & 20.87 & 28.29 & $0.00 \mathrm{c}$ & 0.00 \\
\hline \multirow[t]{2}{*}{ Metconazole $^{1}$} & $15.75 \pm$ & $19.23 \pm$ & $24.50 \pm$ & $30.99 \pm$ & $68.75 \pm$ & $6.78 \pm$ & $46.25 \pm$ & $53.75 \pm$ \\
\hline & $4.79 \mathrm{~b}$ & 24.55 & $4.51 \mathrm{~b}$ & 12.70 & 30.03 & 40.73 & $21.26 \mathrm{a}$ & 21.26 \\
\hline \multirow[t]{2}{*}{ Azoxystrobin } & $16.25 \pm$ & $16.67 \pm$ & $26.25 \pm$ & $26.06 \pm$ & $72.50 \pm$ & $1.69 \pm$ & $100.00 \pm$ & $0.00 \pm$ \\
\hline & $7.63 \mathrm{~b}$ & 39.14 & $4.79 \mathrm{~b}$ & 13.48 & 34.03 & 46.15 & $0.00 \mathrm{c}$ & 0.00 \\
\hline \multirow[t]{2}{*}{ Cuprous oxide } & $17.00 \pm$ & $12.82 \pm$ & $28.25 \pm$ & $20.42 \pm$ & $36.88 \pm$ & $50.00 \pm$ & $100.00 \pm$ & $0.00 \pm$ \\
\hline & $4.69 \mathrm{~b}$ & 24.05 & $5.74 \mathrm{~b}$ & 16.16 & 5.15 & 6.99 & $0.00 \mathrm{c}$ & 0.00 \\
\hline \multirow[t]{2}{*}{ Chlorothalonil } & $19.50 \pm$ & $0.00 \pm$ & $23.75 \pm$ & $33.10 \pm$ & $60.63 \pm$ & $17.80 \pm$ & $100.00 \pm$ & $0.00 \pm$ \\
\hline & $5.80 \mathrm{~b}$ & 29.75 & $2.87 \mathrm{~b}$ & 8.09 & 29.47 & 39.95 & $0.00 \mathrm{c}$ & 0.00 \\
\hline \multirow[t]{2}{*}{ Check } & $19.50 \pm$ & $0.00 \pm$ & $35.50 \pm$ & $0.00 \pm$ & $73.75 \pm$ & $0.00 \pm$ & $100.00 \pm$ & $0.00 \pm$ \\
\hline & $3.11 \mathrm{~b}$ & 0.00 & $5.69 \mathrm{~b}$ & 0.00 & 24.71 & 0.00 & $0.00 \mathrm{c}$ & 0.00 \\
\hline CV $(\%)$ & 12.64 & - & 9.76 & - & 24.85 & - & 20.33 & - \\
\hline
\end{tabular}


${ }^{1}$ Those fungicides had a phytotoxic effect

${ }^{2}$ Values presented after the symbol \pm are standard deviations

${ }^{3}$ Means followed by the same letters in columns were not different when compared by the Scott-Knott statistical test at $5 \%$ of probability $(P \leq 0.05)$

Fungicides used in the tomato crop to control other diseases were not able to control above $70 \%$ of the incidence of $S$. lycopersici on average. For severity, the fungicides which have a percentage of control above $70 \%$ were boscalide, cymoxanil + mancozeb, azoxystrobin + mancozeb, metalaxyl-M + mancozeb and metalaxyl-M + chlorothalonil $(88.73 ; 81.91 ; 80.35 ; 79.38$ and $77.03 \%$, on average), when applied preventively (Table 7).

Table 7 In vivo assays measuring incidence and severity of septoriose affected by preventive treatment used in the tomato crop to control other diseases

\begin{tabular}{|c|c|c|c|c|c|c|c|c|}
\hline \multirow[t]{2}{*}{ Non-registered fungicides } & \multicolumn{2}{|c|}{ Exp. 1} & \multicolumn{2}{|c|}{ Exp. 2} & \multicolumn{2}{|c|}{ Exp. 1} & \multicolumn{2}{|c|}{ Exp. 2} \\
\hline & Incidence & Control (\%) & Incidence & Control (\%) & Severity & Control (\%) & Severity & Control (\%) \\
\hline \multirow[t]{2}{*}{ Azoxystrobin + Mancozeb } & $14.00 \pm$ & $49.09 \pm$ & $22.50 \pm$ & $56.94 \pm$ & $20.38 \pm$ & $76.63 \pm$ & $15.94 \pm$ & $84.06 \pm$ \\
\hline & $5.72 \mathrm{a}^{23}$ & 20.78 & $7.14 \mathrm{~b}$ & 6.54 & $13.72 \mathrm{a}$ & 13.72 & $10.96 \mathrm{~b}$ & 10.96 \\
\hline \multirow[t]{2}{*}{ Cymoxanil + Mancozeb } & $14.75 \pm$ & $46.36 \pm$ & $13.25 \pm$ & $74.64 \pm$ & $23.13 \pm$ & $76.88 \pm$ & $13.06 \pm$ & $86.94 \pm$ \\
\hline & $2.36 \mathrm{a}$ & 8.59 & $6.80 \mathrm{a}$ & 13.02 & $4.84 \mathrm{a}$ & 4.84 & $10.31 \mathrm{~b}$ & 10.31 \\
\hline \multirow[t]{2}{*}{ Metalaxyl-M + Mancozeb } & $16.75 \pm$ & $39.09 \pm$ & $25.75 \pm$ & $50.72 \pm$ & $25.00 \pm$ & $75.00 \pm$ & $16.25 \pm$ & $83.75 \pm$ \\
\hline & $7.89 \mathrm{a}$ & 28.69 & $4.99 \mathrm{~b}$ & 9.55 & $11.73 \mathrm{a}$ & 11.73 & $3.06 \mathrm{~b}$ & 3.06 \\
\hline \multirow[t]{2}{*}{ Boscalid } & $18.00 \pm$ & $34.55 \pm$ & $7.50 \pm$ & $85.65 \pm$ & $18.50 \pm$ & $81.50 \pm$ & $4.06 \pm$ & $95.94 \pm$ \\
\hline & $5.83 \mathrm{a}$ & 21.20 & $3.11 \mathrm{a}$ & 5.95 & $9.95 \mathrm{a}$ & 9.95 & $1.53 \mathrm{a}$ & 1.53 \\
\hline \multirow[t]{2}{*}{ Metalaxyl-M + Chlorothalonil } & $20.00 \pm$ & $27.27 \pm$ & $24.50 \pm$ & $53.11 \pm$ & $21.25 \pm$ & $78.75 \pm$ & $24.69 \pm$ & $75.31 \pm$ \\
\hline & $5.10 \mathrm{a}$ & 18.54 & $5.80 \mathrm{~b}$ & 11.11 & $7.14 \mathrm{a}$ & 7.14 & $17.51 \mathrm{c}$ & 17.51 \\
\hline \multirow[t]{2}{*}{ Copper oxychloride } & $23.00 \pm$ & $16.36 \pm$ & $46.00 \pm$ & $11.96 \pm$ & $100.00 \pm$ & $0.00 \pm$ & $100.00 \pm$ & $0.00 \pm$ \\
\hline & $4.08 \mathrm{~b}$ & 14.85 & $6.06 \mathrm{~d}$ & 11.59 & $0.00 \mathrm{~d}$ & 0.00 & $0.00 \mathrm{e}$ & 0.00 \\
\hline \multirow{4}{*}{$\begin{array}{l}\text { Propamocarb hydrochloride + } \\
\text { Fluopicolide } \\
\text { Propamocarb hydrochloride }\end{array}$} & $23.75 \pm$ & $13.64 \pm$ & $39.25 \pm$ & $24.88 \pm$ & $100.00 \pm$ & $0.00 \pm$ & $100.00 \pm$ & $0.00 \pm$ \\
\hline & $2.63 \mathrm{~b}$ & 9.56 & $3.59 \mathrm{c}$ & 6.88 & $0.00 \mathrm{~d}$ & 0.00 & $0.00 \mathrm{e}$ & 0.00 \\
\hline & $24.00 \pm$ & $12.73 \pm$ & $40.50 \pm$ & $22.49 \pm$ & $100.00 \pm$ & $0.00 \pm$ & $100.00 \pm$ & $0.00 \pm$ \\
\hline & $2.45 \mathrm{~b}$ & 8.91 & $6.03 \mathrm{c}$ & 11.54 & $0.00 \mathrm{~d}$ & 0.00 & $0.00 \mathrm{e}$ & 0.00 \\
\hline \multirow[t]{2}{*}{ Procymidone } & $24.00 \pm$ & $12.73 \pm$ & $39.75 \pm$ & $23.92 \pm$ & $100.00 \pm$ & $0.00 \pm$ & $100.00 \pm$ & $0.00 \pm$ \\
\hline & $4.97 \mathrm{~b}$ & 18.06 & $12.20 \mathrm{c}$ & 23.36 & $0.00 \mathrm{~d}$ & 0.00 & $0.00 \mathrm{e}$ & 0.00 \\
\hline \multirow[t]{2}{*}{ Famoxadone + Mancozeb } & $24.50 \pm$ & $10.91 \pm$ & $24.25 \pm$ & $53.59 \pm$ & $48.13 \pm$ & $51.88 \pm$ & $16.56 \pm$ & $83.44 \pm$ \\
\hline & $5.07 \mathrm{~b}$ & 18.42 & $4.50 \mathrm{~b}$ & 8.61 & $19.08 \mathrm{~b}$ & 19.08 & $8.50 \mathrm{~b}$ & 8.50 \\
\hline \multirow[t]{2}{*}{ Metiram } & $24.75 \pm$ & $10.00 \pm$ & $41.00 \pm$ & $21.53 \pm$ & $76.88 \pm$ & $23.13 \pm$ & $28.75 \pm$ & $71.25 \pm$ \\
\hline & $1.26 \mathrm{~b}$ & 4.58 & $5.83 c$ & 11.16 & $2.39 \mathrm{c}$ & 2.39 & $10.85 \mathrm{c}$ & 10.85 \\
\hline \multirow[t]{2}{*}{ Copper hydroxide } & $25.25 \pm$ & $8.18 \pm$ & $46.25 \pm$ & $11.48 \pm$ & $100.00 \pm$ & $0.00 \pm$ & $100.00 \pm$ & $0.00 \pm$ \\
\hline & $2.87 \mathrm{~b}$ & 10.44 & $3.30 \mathrm{~d}$ & 6.32 & $0.00 \mathrm{~d}$ & 0.00 & $0.00 \mathrm{e}$ & 0.00 \\
\hline
\end{tabular}


Table 7 Continued.

\begin{tabular}{|c|c|c|c|c|c|c|c|c|}
\hline \multirow[t]{2}{*}{ Non-registered fungicides } & \multicolumn{2}{|c|}{ Exp. 1} & \multicolumn{2}{|c|}{ Exp. 2} & \multicolumn{2}{|c|}{ Exp. 1} & \multicolumn{2}{|c|}{ Exp. 2} \\
\hline & Incidence & Control (\%) & Incidence & Control (\%) & Severity & Control (\%) & Severity & Control (\%) \\
\hline \multirow[t]{2}{*}{ Azoxystrobin + Diphenoconazole } & $26.00 \pm$ & $5.45 \pm$ & $40.50 \pm$ & $22.49 \pm$ & $37.19 \pm$ & $62.84 \pm$ & $50.00 \pm$ & $50.00 \pm$ \\
\hline & $2.94 \mathrm{~b}$ & 10.71 & $3.32 \mathrm{c}$ & 6.35 & $7.10 \mathrm{~b}$ & 7.10 & $17.56 \mathrm{~d}$ & 17.56 \\
\hline \multirow[t]{2}{*}{ Trifloxystrobin + Tebuconazole } & $26.75 \pm$ & $2.73 \pm$ & $43.50 \pm$ & $16.75 \pm$ & $85.00 \pm$ & $15.00 \pm$ & $80.63 \pm$ & $19.38 \pm$ \\
\hline & $4.11 \mathrm{~b}$ & 14.96 & $7.14 \mathrm{~d}$ & 13.67 & $22.45 \mathrm{c}$ & 22.45 & $13.75 \mathrm{e}$ & 13.75 \\
\hline \multirow[t]{2}{*}{ Captan } & $27.00 \pm$ & $1.82 \pm$ & $37.50 \pm$ & $28.23 \pm$ & $72.50 \pm$ & $27.50 \pm$ & $39.69 \pm$ & $60.31 \pm$ \\
\hline & $2.94 \mathrm{~b}$ & 10.71 & $5.57 \mathrm{c}$ & 10.66 & $13.69 \mathrm{c}$ & 13.69 & $21.32 \mathrm{~d}$ & 21.32 \\
\hline Isopropyl bentiavalicarb + & $28.25 \pm$ & $0.00 \pm$ & $39.75 \pm$ & $23.92 \pm$ & $100.00 \pm$ & $0.00 \pm$ & $36.56 \pm$ & $63.44 \pm$ \\
\hline Fluazinam & $4.99 \mathrm{~b}$ & 0.00 & $3.95 \mathrm{c}$ & 7.56 & $0.00 \mathrm{~d}$ & 0.00 & $22.04 \mathrm{~d}$ & 22.04 \\
\hline \multirow[t]{2}{*}{ Iprodione } & $28.25 \pm$ & $0.00 \pm$ & $54.75 \pm$ & $0.00 \pm$ & $100.00 \pm$ & $0.00 \pm$ & $100.00 \pm$ & $0.00 \pm$ \\
\hline & $4.35 \mathrm{~b}$ & 0.00 & $8.38 \mathrm{~d}$ & 0.00 & $0.00 \mathrm{~d}$ & 0.00 & $0.00 \mathrm{e}$ & 0.00 \\
\hline \multirow[t]{2}{*}{ Dimethomorph } & $28.75 \pm$ & $0.00 \pm$ & $37.00 \pm$ & $29.19 \pm$ & $100.00 \pm$ & $0.00 \pm$ & $100.00 \pm$ & $0.00 \pm$ \\
\hline & $3.50 \mathrm{~b}$ & 0.00 & $6.22 \mathrm{c}$ & 11.90 & $0.00 \mathrm{~d}$ & 0.00 & $0.00 \mathrm{e}$ & 0.00 \\
\hline Isopropyl bentiavalicarb + & $28.75 \pm$ & $0.00 \pm$ & $36.00 \pm$ & $31.10 \pm$ & $47.50 \pm$ & $52.50 \pm$ & $24.69 \pm$ & $75.31 \pm$ \\
\hline Chlorothalonil & $7.27 \mathrm{~b}$ & 0.00 & $6.88 \mathrm{c}$ & 13.17 & $14.72 \mathrm{~b}$ & 14.72 & $6.32 \mathrm{c}$ & 6.32 \\
\hline \multirow[t]{2}{*}{ Mandipropamid } & $29.00 \pm$ & $0.00 \pm$ & $46.00 \pm$ & $11.96 \pm$ & $100.00 \pm$ & $0.00 \pm$ & $100.00 \pm$ & $0.00 \pm$ \\
\hline & $4.32 \mathrm{~b}$ & 0.00 & $5.16 \mathrm{~d}$ & 9.88 & $0.00 \mathrm{~d}$ & 0.00 & $0.00 \mathrm{e}$ & 0.00 \\
\hline \multirow[t]{2}{*}{ Cymoxanil + Famoxadone } & $29.25 \pm$ & $0.00 \pm$ & $39.50 \pm$ & $24.40 \pm$ & $100.00 \pm$ & $0.00 \pm$ & $100.00 \pm$ & $0.00 \pm$ \\
\hline & $4.03 \mathrm{~b}$ & 0.00 & $11.93 \mathrm{c}$ & 22.83 & $0.00 \mathrm{~d}$ & 0.00 & $0.00 \mathrm{e}$ & 0.00 \\
\hline \multirow[t]{2}{*}{ Copper oxychloride + Mancozeb } & $29.75 \pm$ & $0.00 \pm$ & $36.75 \pm$ & $29.67 \pm$ & $94.38 \pm$ & $5.63 \pm$ & $40.31 \pm$ & $59.69 \pm$ \\
\hline & $10.44 \mathrm{~b}$ & 0.00 & $2.87 \mathrm{c}$ & 5.50 & $6.57 \mathrm{~d}$ & 6.57 & $6.16 \mathrm{~d}$ & 6.16 \\
\hline \multirow[t]{2}{*}{ Kasugamycin } & $31.25 \pm$ & $0.00 \pm$ & $45.75 \pm$ & $12.44 \pm$ & $100.00 \pm$ & $0.00 \pm$ & $100.00 \pm$ & $0.00 \pm$ \\
\hline & $2.75 \mathrm{~b}$ & 0.00 & $7.93 \mathrm{~d}$ & 15.18 & $0.00 \mathrm{~d}$ & 0.00 & $0.00 \mathrm{e}$ & 0.00 \\
\hline \multirow[t]{2}{*}{ Fluazinam } & $31.50 \pm$ & $0.00 \pm$ & $25.50 \pm$ & $51.20 \pm$ & $61.88 \pm$ & $38.13 \pm$ & $13.19 \pm$ & $86.81 \pm$ \\
\hline & $4.12 \mathrm{~b}$ & 0.00 & $9.98 \mathrm{~b}$ & 19.11 & $11.06 \mathrm{c}$ & 11.06 & $6.69 \mathrm{~b}$ & 6.69 \\
\hline \multirow[t]{2}{*}{ Check } & $27.50 \pm$ & - & $52.25 \pm$ & - & $100.00 \pm$ & - & $100.00 \pm$ & - \\
\hline & $5.51 \mathrm{~b}$ & & $7.14 \mathrm{~d}$ & & $0.00 \mathrm{~d}$ & & $0.00 \mathrm{e}$ & \\
\hline Pyrimethanil $^{1}$ & - & - & - & - & - & - & - & - \\
\hline CV $(\%)$ & 9.22 & & 9.68 & & 8.74 & & 12.08 & \\
\hline
\end{tabular}

${ }^{1}$ Those fungicides had a phytotoxic effect

${ }^{2}$ Values presented after the symbol \pm are standard deviations

${ }^{3}$ Means followed by the same letters in columns were not different when compared by the Scott-Knott statistical test at $5 \%$ of probability $(P \leq 0.05)$

In the field experiment, for the check treatment the disease incidence and severity was $89.28 \pm 6.40$ and $100 \pm 0.00$, respectively. The pyraclostrobin alone was ineffective against septoriose since the disease incidence and severity was $87.56 \pm 3.19(1.94 \% \pm 3.57$ of control) and $100 \pm$ 
0.00 ( $0 \%$ of control), respectively. While for the pyraclostrobin + fluxapiroxad the disease incidence and severity was $4.08 \pm 3.58$ (95.42 \pm 4.01 of control) and $0.62 \pm 0.15$ (99.31 \pm 0.17 of control), respectively. The coefficient of variation for incidence and severity was $7.83 \%$ and $12.75 \%$, respectively.

Comparing the results in vitro between pyraclostrobin and pyraclostrobin + fluxapyroxad in equivalent doses of pyraclostrobin, we observed that pyraclostrobin did not control the $S$. lycopersici, because there was no halo inhibition formed, while pyraclostrobin + fluxapyroxad induced an inhibition halo of $19.33 \pm 2.63 \mathrm{~mm}$.

Pyraclostrobin pulverization had no harmful effect on the tomato leaves compared to the plants without fungicides application (Fig. 2b). Pyrimethanil pulverization caused white-brown spots on the tomato leaves (Fig. 2d). Metconazole and tebuconazole deformed and delayed leaves development (Fig. 2c, e). Tetraconazole promoted the shriveling of the leaves (Fig. 2f). The harmful effect of some fungicides also affected the growth of the plant, since the height $(\mathrm{mm})$ of the check, pyraclostrobin, pyrimethanil, metconazole, tebuconazole and tetraconazole was $176.72 \mathrm{~mm} \pm 7.08,174.19 \mathrm{~mm} \pm 10.07,174.06 \mathrm{~mm} \pm 6.99,138.87 \mathrm{~mm} \pm 15.50,124.05 \mathrm{~mm} \pm 10.33$ and $91.05 \mathrm{~mm} \pm 14.04$, respectively.

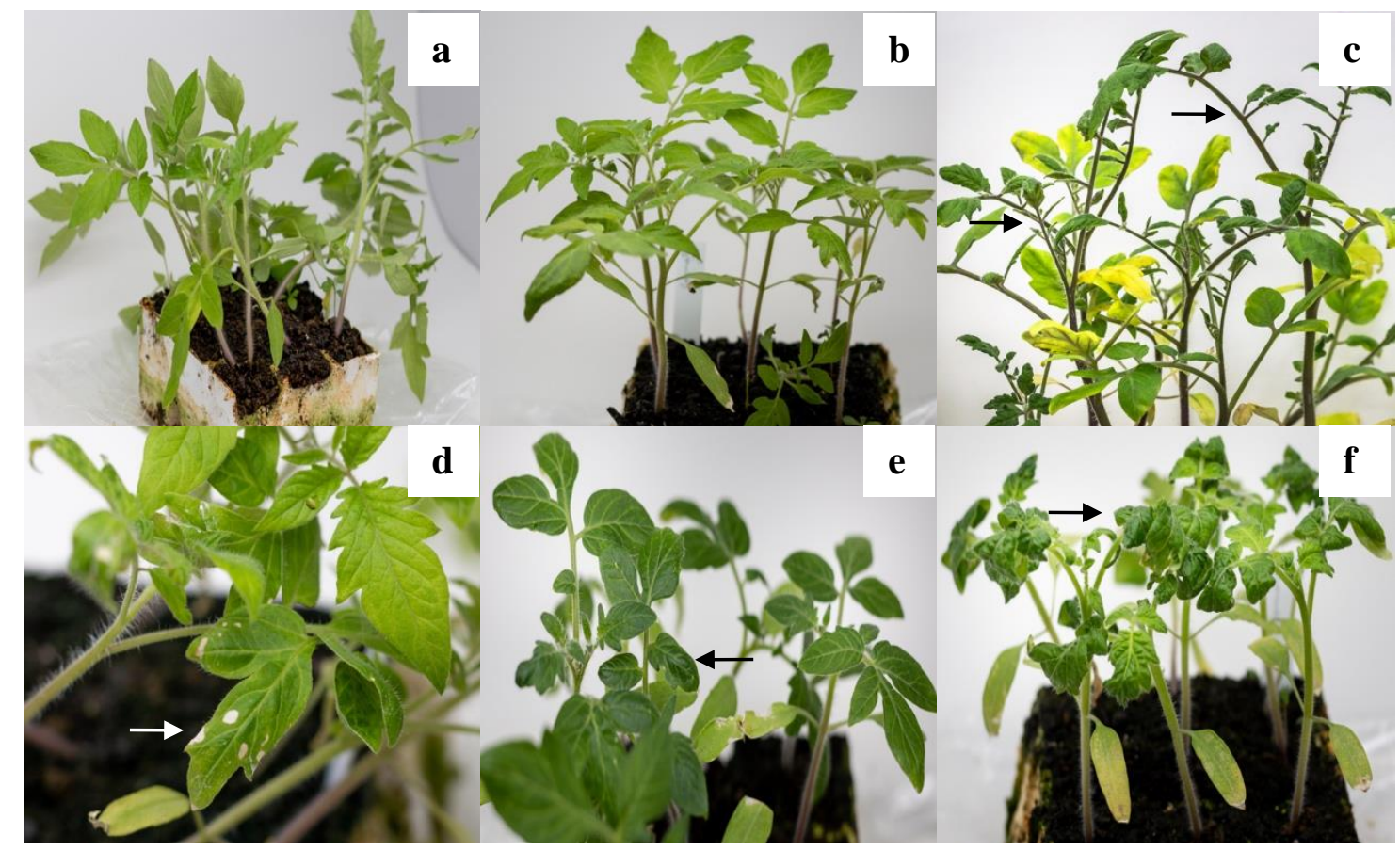

Fig. 2 - Phytotoxicity effect of fungicides applied on tomato leaves. a Tomato plants without the application of fungicides. $\mathrm{b}$ with the application of pyraclostrobin-100ppm. c metconazole-90ppm. $\mathrm{d}$ pyrimethanil-900ppm. e tebuconazole-213ppm. f tetraconazole-75ppm. Arrows indicate the specific symptom of the phytotoxicity triggered by the fungicide. Photos by André Sezerino.

\section{Discussion}

One of the first experiments carried out to determine which active ingredients and doses are efficient in controlling plant pathogens was in vitro. In our work, considering the in vitro experiments for mycelial growth control and spore germination-method 1 (Table 4), there seems to be no adequate separation between fungicides that have high efficiency from those that do not have, when applied to plants. In fact, in vitro test tends to generate many false-positive results, which occur when a compound that inhibits growth in the plate assay fails to inhibit growth in the plant (Oliver \& Hewitt 2014). Sometimes there is no relationship between the $\mathrm{IC}_{50}$ determined in the laboratory and the recommended dose for use in crops (Reis et al. 2016).

On the other hand, method 2 of inhibiting spore germination seems to demonstrate the reality of what happens in vivo, when the fungicide is applied to tomato plants, aiming to control 
S. lycopersici, and with the advantage of not needing a microscope for the spore count. In general, the greater the halo of inhibition caused by the fungicide in method 2, the more efficient the fungicide was in controlling the incidence and severity of S. lycopersici in tomato plants (Tables 4, 5). In this context, we believe that the proposed method can be a fast and effective method for determining fungicide efficiency, aiming at field control. The disadvantage of in vitro methods is that it is impossible to know any deleterious effects to plants caused by applying some fungicides in some doses. In vivo screening is the most time-consuming and expensive and the most predictive of final success (Oliver \& Hewitt 2014).

Considering the rotation of different modes of action recommended by FRAC (2021), fungicides considered inefficient in this work, such as thiophanate-methyl, azoxystrobin and cuprous oxide, could have their label dosage revised by the manufacturers, seeking to improve the efficiency of the product against $S$. lycopersici, making the management of the disease more efficient. The low sensibility of some $S$. lycopersici isolates to azoxystrobin was reported at the dose of 40ppm (Costa 2019). However, higher doses of azoxystrobin may improve the performance of the fungicide (Anand et al. 2014). Despite the salicyl hydroxamic acid (SHAM) was not being used to inhibit the fungal alternative oxidase in vitro, the in vivo assays results corroborate the inefficiency of azoxystrobin or pyraclostrobin, since this via is presumed to be inhibited by secondary metabolites of plants (Liang et al. 2019). This inefficiency may is related to the emergence of the resistant $S$. lycopersici population. For this reason, the use of a single fungicide to control this disease is not recommended herein, as it has a temporary effect and increases the selection pressure for the fungicide used, increasing the chances of resistant spores to the fungicide arise due to adaptability and mutations.

In this work, thiophanate-methyl was not considered efficient. However, Awuah (1997) reported that the dose of $413 \mathrm{ppm}$ delayed the septoriose progress. The adaptability of S. lycopersici isolates to some fungicides became clearer when increasing doses of azoxystrobin, pyraclostrobin and thiophanate-methyl were used, suggesting that the label dosage may not be efficient as it once was in controlling the pathogen. This fact is explained by the adaptation of the isolates, which could trigger the development of resistance against fungicides with just one mode of action. Despite the efficiency of cuprous oxide demonstrated in vitro, in vivo experiments did not confirm its efficiency in controlling S. lycopersici.

At the doses tested, two of the most efficient fungicides against $S$. lycopersici seem to be succinate dehydrogenase inhibitors, which interfere in the fungus's energy generation (Keon et al. 1991), herein represented by fluxapyroxad and boscalid. Silva (2018) also showed an efficient control of septoriose by using fluxapyroxad + pyraclostrobin at the dose of 50ppm $+99 \mathrm{ppm}$ of the active ingredient, respectively.

The efficiency of mancozeb, a multi-site fungicide, is related to the recommended dose since, in the copper oxychloride+mancozeb formulation, which was considered ineffective in controlling septoriose, the dose of mancozeb is $218.18 \%$ lower than other formulations containing the active ingredient (azoxystrobin + mancozeb; cymoxanil + mancozeb), which obtains a severity control around $80 \%$. It seems to happen with the chlorothalonil as well. Based on the results, fungicides with mancozeb or chlorothalonil should be present at a minimum of 1900 or 1200ppm, respectively, to achieve at least $70 \%$ of septoriose control. Mancozeb is reported to be efficient against $S$. lycopersici at the dose of 2500ppm in combination with carbendazim (2000ppm of active ingredient) (Lal et al. 2015) and at the dose of 1260ppm in combination with carbendazim (240ppm) (Naik et al. 2010), while chlorothalonil at the dose of 2969ppm was reported to reduce the final foliar disease development of septoriose (Poysa et al. 1993). In addition, chlorothalonil and azoxystrobin as preventive treatment, and difenoconazole and metconazole as curative treatments were reported to be efficient in controlling septorioses (Baldicera et al. 2020).

The control of septoriose should be exclusively preventive, as all the recommended fungicides have an efficiency below $70 \%$ when used curatively (Table 6). The effect of dose on the emergence of resistance has been the subject of intense debate (Shaw \& Pijls 1994, Zziwa \& Burnett 1994). It is now established for the great majority of cases that the lower the dose the lower 
the risk of resistance because the selection pressure is higher at higher doses (Van den Bosch et al. 2011). However, this lower dose must be sufficient to control the disease in the field, even in an excellent condition to pathogen development and disease progress. Rotate fungicides based on the mode of action is recommended to avoid or delay the emergence of the resistance, but the subsequent fungicide must be effective and recommended in an effective dose. Fungicides that act via one specific site such IDMs (triazoles), IQes (strobilurins) and ISDHs (fluxapyroxad and boscalid), only one mutation in the target of the fungicide action may result in a resistant strain, and therefore, they should be used in a system of rotation modes of action. To mitigate the outcome of resistant $S$. lycopersici strains, we recommended herein the use of one-site fungicides only combined with multisite fungicides as such mancozeb or chlorothalonil, or combined with efficient protective fungicides, always rotating the mode of action as recommended by FRAC (2021).

The fungicidal action (fungitoxicity) is a function of the concentration in the leaf tissue. Sun, rain and metabolization through the plant will reduce the fungicide effective concentration. In crops like tomato, the spraying of protective fungicides is weekly in an open field, and in case where there is a rainfall of $13 \mathrm{~mm}$ it removes the deposit of protective fungicides in tomato (Reis et al. 2016), requiring a reapplication. In fact, the half-lives of the fungicides applied on plants rarely extend to more than one week. Azoxystrobin, boscalid, captan, chlorothalonil, difenoconazole, famoxadone, fluazinam, iprodione, mancozeb, mandipropamide, metalaxyl-M, procymidone, pyraclostrobin, tebuconazole and tetraconazole have $3.53 ; 6.63 ; 4.45 ; 5.02 ; 5.02 ; 5.63 ; 3.77 ; 6.92$; $4.69 ; 3.46 ; 3.74 ; 9.89 ; 3.90 ; 7.67$ and 5.27 half-lives in days, respectively, measure by dissipation (Fantke et al. 2014). In addition, the deposition does not always cover or protect all infection sites (Reis et al. 2016). The higher the dose, the longer the protection period (Reis et al. 2016), but the dose used must follow the fungicide label instructions to keep the risk of resistance low and to comply with current legislation.

IDM have plant growth-regulating activity by likely inhibiting the production of gibberellins and sterol biosynthesis (phytosterol), which slows or reduces growth in some plants, and the increase in the green colour is the result of the increase in the chlorophyll content and the activity of the enzyme nitrate reductase (Reis et al. 2016). The overexpression of those characteristics might lead to the occurrence of plant phytotoxicity as observed for metconazole, tebuconazole and tetraconazole at the doses used. It is important to note that the phytotoxicity is dependent on the type of fungicide, dose and specific environmental conditions, and might vary according to the plant cultivar.

Based on the results of the in vivo experiments, a crucial factor for the study of fungicide efficiency is the existence of an optimum favourable environment for the pathogen and the progress of the disease. When the environment is unfavourable, even though the disease occurs, it does not occur with great intensity, leading to wrong conclusions about the fungicides efficiency since it also depends on the environmental conditions. Similar to what exists for soybeans (Godoy et al. 2020) we suggest a joint action program to determine the efficiency of the active ingredients at their recommended doses in several regions with different edaphoclimatic conditions.

Therefore, growers are faced with numerous decisions on how best to use fungicides, choosing which type of fungicide to use and when applying them. Fungicide chosen must be sufficient to control the disease efficiently in the field to ensure higher yields, do not cause any harmful effect on plants and be economically acceptable with good cost/benefits. To manage $S$. lycopersici in tomato plants, the pulverization of multi-sites fungicides (mancozeb, chlorothalonil, propineb or metiram) or fluazinam (protective fungicide) combined with systemic fungicides (fluxapyroxad or difenoconazole) at the doses recommended without a tank mixture and performing the action mode rotation should provide an efficient level of control. The fungicides metiram, fluazinam and fluxapiroxade are recommended to control septoriose in Brazil only when formulated with pyraclostrobin, thiophanate-methyl and pyraclostrobin, respectively.

\section{Acknowledgements}

The authors are thankful to the Agricultural Research and Rural Extension Enterprise of 
Santa Catarina (EPAGRI) and the Foundation for Research and Innovation Support of the State of Santa Catarina (FAPESC) for financing and encouraging the execution of the project that gave rise to this publication. In addition, the authors are thankful to André Sezerino for the photographs in Fig. 2.

\section{References}

Anand YR, Begum S, Dangmei R, Nath PS. 2014 - Evaluation of fungicide azoxystrobin 23\% SC (Coromandel) against leaf spot diseases of tomato. Journal of Agriculture and Technology 1, 77-79.

Awuah RT. 1997 - An evaluation of some systemic fungicides for the control of Septoria leaf spot of tomato. Ghana Journal of Agricultural Science 30, 71-78.

Baldicera AK, Bogo A, Nerbass FR, Becker WF et al. 2020 - Sensibilidade de isolados de Septoria lycopersici e eficácia de fungicidas no controle de septoriose em tomateiro. Revista de Ciências Agroveterinárias 19, 159-170.

Bhardwaj CL, Thakur DR, Jamwal RS. 1995 - Effect of fungicide spray and staking on diseases and disorders of tomato (Lycopersicon esculentum). Indian Journal of Agricultural Sciences $65,149-151$.

Costa CA. 2019 - Identificação de isolados de Septoria lycopersici do tomateiro e sensibilidade a fungicidas. $102 \mathrm{p}$. Thesis.

Dillard HR, Johnston SA, Cobb AC, Hamilton GH. 1997 - An assessment of fungicide benefits for the control of fungal diseases of processing tomatoes in New York and New Jersey. Plant Disease 81, 677-681.

Douglas SM. 2008 - Septoria leaf spot of tomato. The Connecticut Agricultural Experiment Station $1-3$.

Elmer WH, Ferrandino FJ. 1995 - Influence of spore density, leaf age, temperature, and dew periods on Septoria leaf spot of tomato. Plant Disease 79, 287-290.

Fantke P, Gillespie BW, Juraske R, Jolliet O. 2014 - Estimating half-lives for pesticide dissipation from plants. Environmental Science \& Technology 48, 8588-8602.

Fisher DJ, Hayes AL. 1982 - Mode of action of the systemic fungicides furalaxyl, metalaxyl and ofurace. Pesticide science 13, 330-339.

FRAC. 2021 - (Fungicide resistance action committee) https://www.frac.info/fungicide-resistancemanagement (Accessed on July 16, 2021).

Gisi U, Lamberth C, Mehl A, Seitz T et al. 2019 - Carboxylic Acid Amide (CAA) Fungicides. Modern Crop Protection Compounds 2, 845-869.

Godoy CV, Utiamada CM, Meyer MC, Campos HD et al. 2020 - Eficiência de fungicidas para o controle da ferrugem-asiática da soja, Phakopsora pachyrhizi, na safra 2019/2020: resultados sumarizados dos ensaios cooperativos. Embrapa Soja-Circular Técnica (INFOTECA-E) 160, $1-19$.

Joshi MM. 2003 - Fungicides, Cymoxanil. In: Plimmer JR, Gammon DW, Ragsdale NN (eds) Encyclopedia of Agrochemicals 2 New Jesey, Wiley-Interscience, 554-555.

Keon JP, White GA, Hargreaves JA. 1991 - Isolation, characterization and sequence of a gene conferring resistance to the systemic fungicide carboxin from the maize smut pathogen, Ustilago maydis. Current genetics 19, 475-481.

Kilian M, Steiner U. 2003 - Bactericides and fungicides. In: Roberts AV, Debener T, Gudin S (eds) Encyclopedia of Rose Science. Oxford, UK: Elsevier, 190-198.

Kuhn PJ, Pitt D, Lee SA, Wakley G et al. 1991 - Effects of dimethomorph on the morphology and ultrastructure of Phytophthora. Mycological Research 95, 333-340.

Kurozawa C, Pavan MA. 2005 - Doenças do tomateiro. In: Kimati H, Amorim L, Rezende JAM, Bergamin Filho et al. Manual de fitopatologia: doenças das plantas cultivadas. São Paulo, Brazil: Agronômica Ceres 607-626. 
Lal M, Dabbas MR, Singh SK, Kumar S. 2015 - Evaluation of chemical management against Septoria leaf spot of tomato. Annals of Horticulture 8, 208-211.

Liang H, Li J, Luo C, Li J et al. 2019 - Effects of SHAM on the Sensitivity of Sclerotinia sclerotiorum and Botrytis cinerea to QoI Fungicides. Plant disease, 103, 1884-1888.

Luo GANG, Lewis RA. 1992 - Inhibition of RNA polymerase by captan at both DNA and substrate binding sites. Biochemical pharmacology 44, 2251-2258.

Malnati WD. 1993 - Possibilities of including genetic resistance to control tomato septoria leaf spot. Brazilian Phytopathology 18, 469-477.

Martin-Hernandez AM, Dufresne M, Hugouvieux V, Melton R et al. 2000 - Effects of targeted replacement of the tomatinase gene on the interaction of Septoria lycopersici with tomato plants. Molecular plant-microbe interactions 13, 1301-1311.

Monteiro FP, Ogoshi C, Cardoso DA, Valdecir P et al. 2021 - Development and validation of diagrammatic scales to assess septoriose in tomato. Plant Pathology \& Quarantine 11, 115124.

Monteiro FP, Ogoshi C, Maindra LC, Becker WF. 2019 - Culture medium based on tomato leaves for abundant production of conidia from Septoria lycopersici. Asian Journal of Agricultural and Horticultural Research 1-6.

Naik RG, Naik BG, Naik TB. 2010 - Chemical management of Septoria leaf spot disease in tomato. Mysore Journal of Agricultural Sciences 44, 551-555.

Okuyama A, Machiyama N, Kinoshita T, Tanaka N. 1971 - Inhibition by kasugamycin of initiation complex formation on $30 \mathrm{~S}$ ribosomes. Biochemical and biophysical research communications 43, 196-199.

Oliver RP, Hewitt HG. 2014 - Fungicides in crop protection. Cabi Publishing, Wallingford, Oxon, UK. 189p.

Papavizas GC, O’Neill NR, Lewis JA. 1978 - Fungistatic activity of propyl-N[adimethylaminopropyl) carbamate on Pythium spp. and its reversal by sterols. Phytopathology 68, 1667-1671.

Parker SK, Nutter JFW, Gleason ML. 1997 - Directional spread of Septoria leaf spot in tomato rows. Plant Disease 81, 272-276.

Poysa V, Brammall RA, Pitblado RE. 1993 - Effects of foliar fungicide sprays on disease and yield of processing tomatoes in Ontario. Canadian Journal of Plant Science 73, 1209-1215.

Poysa V, Tu JC. 1993 - Response of cultivars and breeding lines of Lycopersicon spp. to Septoria lycopersici. Canadian Plant Disease Survey 73, 9-13.

Reis EM, Reis AC, Carmona MA. 2016 - Manual de fungicidas: Guia para o controle químico racional de doenças de plantas. 7 ed. Passo Fundo: Berthier. 280 p.

Seymour CP, Ridings WH. 1980 - Septoria leaf spot of tomato. Plant Pathology Circular 210, 1-2.

Shaw MW, Pijls CFN. 1994 - The effect of reduced dose on the evolution of fungicide resistance in Septoria tritici. Monographs-british crop protection council, 47-47.

Silva JO. 2018 - Métodos de avaliação de severidade de septoriose no tomateiro e eficácia de fungicidas. 20 p. Dissertation.

Sutton BC, Waterston JM. 1966 - Septoria lycopersici. Kew: Common wealth Mycological Institute. Descriptions of pathogenic fungi and bacteria 89, 1-2.

Stevenson WR. 1991 - Septoria leaf spot. In: Jones JB, Jones JP, Stall et al. Compendium of tomato diseases St. Paul: APS. 22p.

Sohi MS, Sokhi SS. 1974 - Morphological, physiological and pathological studies in Septoria lycopersici Indian Phytopathology 26, 666-673.

Toquin V, Latorse MP, Beffa R. 2019 - Fluopicolide: A New Anti-oomycete Fungicide. Modern Crop Protection Compounds 2, 871-878.

Van Den Bosch F, Paveley N, Shaw M, Hobbelen P. et al. 2011 - The dose rate debate: does the risk of fungicide resistance increase or decrease with dose? Plant Pathology 60, 597-606. 
Vitoratos AG. 2014 - Mode of action and genetic analysis of resistance to fluazinam in Ustilago maydis. Journal of Phytopathology 162, 737-746.

Wessels S, Ingmer H. 2013 - Modes of action of three disinfectant active substances: a review. Regulatory toxicology and pharmacology 67, 456-467.

Zitter TA. 1987 - Septoria Leaf Spot of Tomato. Vegetable crops - Cornell Cooperative Extension, 735-780.

Zziwa MCN, Burnett FJ. 1994 - The effect of reduced doses on the sensitivity of powdery mildew to fenpropimorph in barley field trials. Monographs-british crop protection council, 303-303. 